development. By March 31, 1948, local education authorities are obliged, with minor exceptions, to submit their schemes of further education to the Ministry. Many of them have already begun, and even the backward authorities will have something to promise, if not to display, by the appointed day.

Further education may henceforth hope to enjoy something better than the status of a lesser mandated territory. But a sentimental ardour for its benefits is not enough. What are especially required during these next few years are practicable schemes, reliable progress reports, and a brisk exchange of ideas. The first number of Further Education reveals a realistic purpose in providing these requirements, and is not afflicted by that sense of piety which so often besets ventures which want to advance human progress. In writing or talking about further education it is better to be hard-boiled than half-baked, and one of the characteristics of this new magazine is its preoccupation with ways and means. Its editor, Mr. J. Mackay Mure, is a fẹrvent educationist, and his management of the paper's policy is an assurance that it will keep both feet on the ground. From the first number, it is plain that he intends to take full advantage of the terms of reference embodied in the paper's title. Further education has as much to do with vocational training as with the pursuit of culture, and the more we can be led to considering them as part of a common way of life the sooner shall we discern their relevance to each other. One final merit of this new monthly must be mentioned, and that is the lively quality of most of its articles. Nowhere has the boll-weevil of jargon made greater ravages than in educational journalism, and it is a welcome relief to find it entirely absent from these pages.

\section{The Ray Society}

THE annual general meeting of the Ray Society, now in its hundred and third year, was held on March 21. During the past year the Society lost by retirement owing to ill-health the services of its two senior officers, Sir Sidney Harmer, president since 1931, and Dr. W. T. Calman, secretary since 1919. Resolutions were passed unanimously thanking them for their distinguished services to the Society. Prof. F. E. Weiss having expressed the wish to retire from the office of honorary treasurer, his resignation was accepted with regret. Mr. A. D. Cotton resigned as vice-president. It was announced that Dr. Ben Dawes' volume on "The Trematoda of British Fishes" is ready for distribution, and, owing to the greatly increased costs of publication, this will form the issue to subscribers for the two years 1944 and 1945 . The volume for 1946 will be Dr. Berrill's volume on "British Tunicates", but unexpected difficulties have caused delay in sending this work to press. A volume on Pennant's travels in Europe, edited by Prof. G. R. de Beer, is, however, nearly ready for press, and other works on a wide variety of subjects relating to the natural history of the British Isles are in active preparation. The following were elected officers and new members of council : President, Prof. G. R. de Beer; Hon. Treasurer, Mr. A. C. Townsend; Hon. Secretary, Dr. Errol I. White; Vice-presidents, Prof. F. E. Weiss, Mr. M. A. C. Hinton, Mr. E. R. Martin and Lieut.-Colonel Seymour Sewell ; Members of Council, Mr. A. H. G. Alston, Dr. J. W. Evans, Mr. H. R. Hewer, Dr. George Taylor and Mr. Brian Vesey-Fitzgerald.

\section{New British Ornithological Magazine}

THE first issue of the new Wild Birds Magazine has appeared as a bi-monthly (until the paper ration increases) under the editorship of Mr. Eric Hardy and published from Friars Lodge, Friars Lane, Richmond, Surrey. There are illustrated articles dealing with bird-life at Manchester sewage farm (L. L. Turner), observations at the Yorkshire Naturalists' Union's new bird ringing and observation station at the Spurn by J. Lord, on a heronry (F. A. Lowe), birds of North Devon (N. V. Allen), Dungeness shingle (R. B. Burrowes), etc., while field notes include the first Lancashire record of the European beeeater (Merops apiaster) in the autumn 1946, and the red-backed shrike using the same nesting site in two successive years. An abnormal immigration of waxwings and great grey shrikes into England during the recent winter is noted.

\section{Industrial Uses of Methane}

A PAMPHLET entitled "Chemicals from Methane", by Dr. J. P. Lawrie (pp. 24. Science Services, Ltd., 255 Russell Court, London, W.C.1, 1947. 3s.), deals with possible uses of methane from natural gas which, it is said, is available in important quantities in Great Britain. It is pointed out that large quantities of carbon black are imported from the United States, much of which is made there from natural gas, and it is suggested that this might well be made from native gas. Coke-oven gas is also rich in methane. Other products which might be obtained from methane, according to patent literature quoted, are hydrogen for ammonia synthesis, acetylene by exposure to an electric arc, methyl chloride by chlorination, hydrogen sulphide by reaction with sulphur, oxidation products such as methanol, formaldehyde, and formic acid, and nitromethane. A short bibliography is given.

\section{Royal Institution}

At the anniversary meeting of the members of the Royal Institution held on May 1, the following officers were elected: President, Lord Rayleigh; Secretary, Prof. A. O. Rankine; Treasurer, Dr. R. E. Slade; Managers, Prof. E. N. da C. Andrade, Mr. M. G. Bennett, Prof. H. V. A. Briscoe, Major W. H. Cadman, Sir John Craig, Dr. C. H. Desch, Sir.Alfred Egerton, Dr. E. V. Evans, Dr. W. Jevons, Colonel E. E. B. Mackintosh, Mr. G. S. W. Marlow, Prof. L. C. Martin, Sir Richard Paget, Sir Clifford Patterson, Sir Geoffrey Taylor; Visitors, Mr. J. J. Abraham, Mr. W. E. Watson Baker, Dr. J. H. Brinkworth, Mr. D. I. Duveen, Mr. F. P. Dunn, Mr. P. Evans, Dr. A. T. Fraser, Sir William Halcrow, Prof. F. L. Hopwood, Mr. L. B. W. Jolley, Mr. D. NorthallLaurie, Dr. E. Talbot Paris, Sir Harry Railing, Prof. D. V. Thompson, Prof. H. E. Watson.

\section{Physical Society : Election of Officers}

THE following have been elected officers for 194748 of the Physical Society : President, Prof. G. I. Finch; Vice-Presidents, Sir Edward Appleton, Mr. A. J. Philpot, Prof. H. R. Robinson, Dr. W. D. Wright; Hon. Secretaries, Dr. W. Jevons, Dr. H. H. Hopkins; Hon. Foreign Secretary, Prof. E. N. da C. Andrade; Hon. Treasurer, Dr. H. Shaw; Hon. Librarian, Dr. R. W. B. Pearse; Members of Council, Dr. W. S. Stiles, Dr. C. H. Collie, Prof. J. D. Bernal, Dr. D. Roaf, Dr. A. C. G. Menzies, Prof. R. E. Peierls, Dr. F. C. Toy, Prof. J. F. Allen, Mr. J. H. 